\title{
Transition to Online Higher Education during COVID- 19 Pandemic: Turmoil and Way Forward to Developing Country - Nepal
}

Dhruba Kumar Gautam ( $\nabla$ dhruba.gautam@fom.tu.edu.np)

Tribhuvan University, Faculty of Management https://orcid.org/0000-0001-5377-2475

Prakash Kumar Gautam

Tribhuvan University, Faculty of Management https://orcid.org/0000-0002-2197-3851

\section{Research Article}

Keywords: online class, teaching-learning process, on-class mode of teaching, higher education, anxiety and behavior, COVID-19 pandemic, Nepal

Posted Date: August 18th, 2020

DOI: https://doi.org/10.21203/rs.3.rs-59206/v1

License: (c) (i) This work is licensed under a Creative Commons Attribution 4.0 International License.

Read Full License

Version of Record: A version of this preprint was published at Journal of Research in Innovative Teaching \&amp; Learning on August 18th, 2020. See the published version at https://doi.org/10.1108/JRIT-102020-0051. 


\title{
Transition to Online Higher Education during COVID-19 Pandemic: Turmoil and Way Forward to Developing Country of South Asia- Nepal
}

\author{
Dhruba Kumar Gautam \\ Professor of Management, \\ Faculty of Management, Tribhuvan University, Nepal. \\ dhruba.gautam@,fom.tu.edu.np \\ ORCID: https://orcid.org/0000-0001-5377-2475
}

Prakash Kumar Gautam

Asst. Professor, Faculty of Management

Tribhuvan University, Nepal

gdpconsultingnepal@gmail.com

ORCID: https://orcid.org/0000-0002-2197-3851

\begin{abstract}
Every day thousands of academic institutes suspend their classes and students are staying their home maintaining social distancing due to the fear of COVID-19 pandemic and Nepal is no exception. Realizing this facts, this study aims to explore the factors for the effectiveness of online mode of classes to the on-class course-based students analyzing perception of faculties and students during the COVID-19 pandemic. It is based on exploratory research design following mixed methods of qualitative and quantitative procedures. To build a rich understanding the phenomenon, three-stage data collection procedure: preliminary interview, structural survey, and validation was used. This study revealed triplet as infrastructure-specific, student-specific and teacher-specific as antecedents of effectiveness of online classes to the on-class based courses during pandemic. Technological support, infrastructure availability, faculty, and students' perception have a significant relationship for the effectiveness of the online mode of the teachinglearning process. Students faced anxiety during the COVID-19 pandemic but a higher willingness to learn has little anxiety. There is no association between the effectiveness of the online mode of education and the academic level of students. It significantly contributes to the future management of higher education and digs the future path of online and on-class teaching-learning practices.
\end{abstract}

Keywords: online class; teaching-learning process; on-class mode of teaching; higher education; anxiety and behavior; COVID-19 pandemic; Nepal 


\section{Background}

A member of the family of severe acute respiratory syndrome (SARS) coronavirus-2 (SARS-CoV-

2) first appeared in Wuhan- the capital city of Hubei province of the People's Republic of China in late December 2019, popularly named COVID-19. The World Health Organization (WHO) declared the virus an international public health emergency on January 31, 2020 (WHO, 2020) and declared as a pandemic. During the COVID-19 pandemic, many countries were locked down, business activities closed, and almost all the universities and colleges throughout the world have been closed. Because of the shut down of school and college, 1.5 billion children and youth across the 188 countries are affected for the teaching-learning process which is $72 \%$ of the world's student population by May 11, 2020 (UNESCO, 2020) and the data seems increasing day by day. Realizing the pandemic situation, most of the universities of the world started to teach their on-class courses online through different modes of teaching-learning technologies. Mode of teaching-learning activities are forced to be transformed from classroom teaching into online worldwide and Nepal is no exception. Nepal, irrespective of other nations, is suffering fromCOVID-19 in which more than 1.3 million students (UGC, 2016) of different levels have lost their regular college activities, and universities are forced to withhold their examination and intake schedules.

On-class teaching-learning process of Nepal was suspected from 23 March, 2020 by recommendation of the high-level COVID-19 prevention and control committee of the government of Nepal. With increasing lockdown tenure, academia through formal and informal forums, started a discussion to change the mode of classes and made few arrangement policies to cope with the crisis. All universities of Nepal (except one - distance mode university) and almost all the programs have been running on-class mode of teaching since their inception to before COVID-19 pandemic. These universities were built for on-class practices, having no infrastructure and preparedness for online classes. Faculties and students were not mentally and technically prepared for online mode of teaching and the most important element of online classes i.e. internet facility is barely reliable. Under such circumstances, online teaching in Nepal is more than challenging. To make effective online mode of teaching-learning practices, faculties and students faced the likelihood of psychological stress, anxiety, and trauma on one side and the other side is the fear education practices due to the COVID-19 pandemic. Initially, few faculties of Tribhuvan University in their efforts started delivering their classes online from the very beginning of lockdown in Nepal but the efforts were insufficient in terms of coverage, later Tribhuvan University formally decided to conduct online classes withholding examination schedule. After three weeks of the lockdown, few other universities of Nepal followed Tribhuvan University and decided to continue their on-class mode through online. 
Tribhuvan University, the oldest and largest university of Nepal, has 61 constituent campuses and 1084 affiliated colleges throughout the nation comprising nearly $85 \%$ of the total student population, has around 8000 teaching faculties (UGC, 2016). It represents different economic level students, primarily to lower and middle level. The faculties, administrative staff, and students have difficulties and challenges deciding the online mode of education because of no prior preparedness and convincing level infrastructure institutionally. Though the situation was difficult, the Tribhuvan University took initiative with the formation of a committee for locating major problems of conducting classes online and ruled all its constituent campuses, community and affiliated colleges for online classes wherever possible. This decision posed a new opportunity for a break-through on its quality as well as the coverage along with investment obligation towards the state. Many higher education institutes that are closed due to the COVID-19 pandemic have initially focused on transiting to online teaching (Crowford, et al., 2020) which creates an opportunity for higher education providers to establish their online education strategy.

In context to this scenario, this paper raised some questions. How do higher education students cope up with the hard situation during COVID-19 pandemic especially to the developing countries like Nepal? How is COVID-19 affecting the teaching and learning practices? Does the situation of COVID-19 change the behavior and attitude of students to make a 'new normal' of higher education teaching-learning systems? What are the challenges and way forwards observed by faculties and students during a pandemic period? This study is multidisciplinary work that is widely accepted means for tackling complex problems through innovation and idea generation (Okumus et al., 2018). Different discipline speaks a distinct theoretical base rooted in diverse epistemic goals and strategies (Pedensen, 2016). Few studies have been done relating to COVID-19 from medical and health science (Meng et al., 2020; Gandauri, et al., 2020; Abdulamir \& Hafidh, 2020) however, rare research has been done in the field of education and management. To answer the above questions, this study aimed to explore the effectiveness of online classes of on-class course structure, analyze faculty efforts, perception, and examine the behavior and attitudes of students for online teaching-learning activities during COVID-19 pandemic period.

\section{Reviews of teaching learning-related research during pandemic}

Study shows the need for readiness of academic institutes of almost all countries to transform onclass courses and classes into online during the pandemic period (Basilaia \& Kvavadze, 2020) which helps to reduce the source of spread of COVID-19 as well as maintain social distance. Online teaching-learning makes social distancing and it is already established norms that social distancing slows down virus transmission during an influenza pandemic (Uscher-Pines et al., 2018). Therefore, online learning is being popular during the pandemic period. However, social 
distancing brings fear of uncertainty, physical discomfort, loneliness, anxiety, and stress (Xiang et al., 2020) that negatively affect the teaching-learning process at university. The prolonged social distancing creates loneliness, anxiety, depression, and even mental disorder (Leite et al., 2020; Karen \& Cathy, 2020). The major problems emerged unexpectedly such as violence, racial and ethnical prejudice, environmental and technological disaster have important psychological aspects to the students (Lerner et al., 2020) and the lifestyle of students have been affected because of fear due to COVID-19 pandemic and Nepalese students are no exception.

Online learning is transferring an academic institute into a home institute in which a virtual environment of interaction, simulation, and collaboration enables students to create a world that encompasses anything students can dream up (Thamarana, 2016). However, the psychological impact of quarantine to students is wide-ranging (Brooks et al., 2020). The prolonged closure of college and students home confinement obviously would harm physical and mental health (Leite et al., 2020). A study found that the COVID-19 pandemic is deemed as a threat, causes fear, anxiety, and uncertainty (Ling \& Ho, 2020). During the pandemic period, anxiety was positively associated with health-related anxiety (Wheaton et al., 2012). The understanding of psychological factors to predict anxiety is important. Research reveals that excessive health anxiety likely brings people negative consequences having a serious illness (Wheaton, et al., 2010) and harmful to the likelihood (Taylor et al., 2007). During the pandemic period, avoiding behavior students due to the fear of transmission frequently occurs (Rubin, et. al. 2009) that limits the form of social distancing. Previous studies found that social distancing behavior can damage daily lives, ever lead to greater risk (Brahmbhatt \& Dutta, 2008).

The study of behavioral and psychological responses, and perceptions on the transitional situation of online teaching-learning practices from on-class courses to university students during the COVID-19 pandemic period depends on many factors. Online teaching-learning offers opportunities to transfer learning delivery expanding wide access (Poehlein, 1996), alleviates capacity constrains, and serves a catalyst for institutional transformation (Volery \& Lord, 2000). To obtain opportunities from the online teaching-learning process, three main variablestechnology, faculty characteristics, and student characteristics affect the effectiveness of the delivery of knowledge and skills (Dillon \& Gunawardena, 1995; Leidneer \& Jarvenppa, 1993). The technology devices, design of the program, choice of faculty, responsible curriculum, and supporting stakeholders are necessary and significant for the successful delivery of the lesson in an online environment (Barr \& Miller, 2013). The faculty characteristics play a central role in the effectiveness of online teaching (Collis, 1995). Three factors related to faculty- attitudes towards technology, teaching style, and control over the technology influence the learning outcomes (Webster \& Hackley, 1997). Hence, designed faculty is essential for the overall coordination and 
development of online courses (Haynes et al., 1997). The designed faculty is trained faculty who can improve students learning and facilitates to attain learning goals (Ludeman et al., 2009). In such a condition, online learning integrates several technologies to enable opportunities through asynchronous and synchronous (Reid, 1999).

Proper technology suitable to the online course teaching-learning process allows students to become more active learning than passive recipients (Candy et al., 1994). The richness of technology and institutional capabilities influence the effectiveness of online teaching-learning practices (Daft \& Lengel, 1986) though Nepalese academic institutions and faculties are characterized by less organizational efforts for appropriate technology to create and disseminate knowledge (Author, 2012). The use of technology plays an important role in teaching methods of faculties which supports the improvement of students' achievement. Compared with experimentalcontrol groups, those students who do not use technology and practices of traditional methods of learning have lower academic performance by $15.5 \%$ than those who use technology (Fang et al., 2019). While evaluating online mode of teaching it is found that there are little or no differences in student's performance between online education and face to face instructions (Wetzel et al., 1994), between video instruction and face to face instructions (Storck \& Sproull, 1995). To improve students' performance on the online teaching process, live broadcast, smooth teacherstudent communication, instant feedback from the teacher, and a true mentor and campaign faculty attitude are essential (Yao et al., 2020). The teaching strategies and methods used by faculties impact on the performance of students (Hattie, 2015). But attention should be paid to the institutional resources and public supports. The poorly resourced institutions and socially disadvantaged learners who have limited access to technology and internet adversely impact on students' ability to engage in online teaching-learning environment (Crowford, et al., 2020). Obviously, the health of college students is significantly affected when they faced public health emergencies. Students require attention that help and support for the society, family, and college (Cao at al., 2020).

To be contextual to research geography, all Nepali universities, teaching on-class courses before COVID-19 pandemic (except one i.e. open university), haven't their own online learning 'platform' generally called 'Learning Management System' (LMS). The LMS is a place designed to meet students, interact, assign, material distribution, and grading students virtually. Because of having no institutional LMS almost all academic institutes are using commercial platforms like Google, Microsoft, Zoom, and others. Generally, there are two basic online teaching modes. One 'asynchronous' also called 'recorded' in which faculty prepare recorded contents in advance and students watch them online. There was no possibility of online communication between faculty and students. It is like self-study distributing knowledge materials. Second, 'synchronous' is called 
'live broadcasting' through which faculty teach as real-time interaction and communicate with students. This study covers the synchronous mode of online teaching-learning practices during the COVID-19 pandemic in which the population of this study is students of Tribhuvan University who are switching on-class courses into online without having advanced 'knowledge materials'.

\section{Study Design}

We followed exploratory research design including mixed methods of qualitative and quantitative. Exploratory research design helps to build a rich understanding of the phenomenon and conceptual implications implied with inquiry logic and explanation (Bamberger, 2018). Realizing these facts, this study incorporated three stages of data collection and analysis: first interview, second survey, and finally interview. The first stage interview, to understand the situation of the pandemic, we explored students' interest, their technological skills and facilities, perception towards faculties, their eagerness to learn, anxiety and learning attitudes, along with multiple issues of online education, preparation, perception, and behavior. This process helps to design questionnaires for second stage structural surveys. Based on first step interview findings, the second step of an online structural survey questionnaire designed and distributed to the students of different programs in higher education enrolled in different academic institutes inside Kathmandu valley, the capital of Nepal and outside Kathmandu. To identify the true and accurate pictures, only those students who had attended on-class courses online at least two times during the pandemic period of COVID-19 were considered as respondents. The exploratory examination highlighted several characteristics particularly notable to the triad factors- institutions, faculties, and students. In a third stage, structured field interviews were assessed with faculties who were engaged to teach online classes during a pandemic period. This third stage interview supports the acceptability of examination held in the first and second stages that adds value to the research. This sequential pattern of a threestage mixed method of qualitative and quantitative research helps cross-validate credible, and acceptable explanations of psychological and behavioral responses at higher education regarding transforming on-class teaching practice into online mode of teaching.

\section{Stage One: Interview Findings}

For the screening of ideas and phenomenon to the quantitative survey, altogether 15 students who were attending on-class courses online during the COVID-19 pandemic were selected through snowball sampling. Among the students' dwelling area, 10 were from Kathmandu and 5 were residing out of Kathmandu valley. Students studying Master's Degree only in an online class were selected for the interview realizing that they are normally mature (having age at least 22 years or above) having a good understanding of the complex situation and of research phenomenon. As research norms, we took confidence in the name list of students. One of the common questions was asked to all respondents regarding the stress they felt after the pandemic and lockdown 
situation in Nepal. All the respondents reacted that they were tense of continuation and completion of their degree as the majority of students in Nepal take the Master level as the finishing line of their formal education. Some students showed their strong conviction on poor infrastructure facilities for online classes in their home i.e. internet strength, regular power supply, and devices like laptops and smartphones. Few of them reported the decision regarding online classes 'is not for their favor and will not be effective'. One of the students (age 25) of Master of Business Studies (MBS) program replied:

"...university did not mention anything about online teaching at the time of admission. I have no laptop and my parents are not able to bear the cost of laptops and the internet. How can I study online and complete my course? I am living in a single rented room having $10^{*} 12$ and spending 44 days in that room because of lockdown. In this situation, how can I concentrate on the learning process? Whether I have to think about food, money, family, health, or study for course completion? At least, government and university faculties should think about the constraints of students for the teaching-learning process during a pandemic period. I think students with stressful mind and anxiety from COVID-19 pandemic cannot learn properly. If online classes will be run, effectiveness will be almost nothing..."

Some students noticed that the knowledge and skills to teach online by faculties is not satisfactory. Students need frequent support even to share their PowerPoint text and recording presentation, assigning work, and monitoring students' progress. They showed their doubt on faculty ability to conduct online classes as they have no formal experience in teaching online. Some of the students showed a strong willingness to continue their course online, build their IT skills virtually, eager for e-learning, and complete the course within the stated timeline of the course nature. Besides the above-mentioned weaknesses, they requested the college/university authority to start online classes, encourage students to connect with faculties, and make them engaged in study materials and maintain a teaching-learning environment. They feel that COVID-19 pandemic is not sure to terminate immediately. One student (age 24) of Master of Business Administration ( MBA) replies as:

“...I learn Zoom, Microsoft Team, Google Meet, Voov, and others through virtual sources. First time in my life, I learned how to use them. I joined the MBA program to complete within 2 years and planned to start a career. I can't lose my year which cannot be recovered in my lifetime. No one is perfect and the same as our faculties. But, it is learning by doing and I see that faculties improved a lot within three classes. I request the government and university to run online classes throughout the year and expect positive cooperation from faculties and administration"... 
Academia and political leaders have raised arguments against the decision regarding online classes of Tribhuvan University, i.e. equity to all the students. They argued that the university covers 75 districts out of 77 districts of Nepal and also serves middle and lower-level economic group citizens. Students of Kathmandu and upper-middle-class and upper-class family students have infrastructure as well as admitted to the comparatively technologically good college so that they can be benefited from online education. But what about students from poor class families and students of remote areas who joined in less technology infrastructure institutes? In context to this issue, one student (age 25) of Masters of Business Management (MBM) shared her changing behavior and replied that every threat has some opportunities.

“...I think poor students and remote area students may not get a proper opportunity from this online education. The online teaching process can be started from the capital, gradually in major cities, and lastly in remote areas. In developed countries also all students can not get admission to the top universities, however, minimum requirements are needed for each online course. For this, training to the faculties and administrative staff is required. This opportunity of online learning changes a lot in my life. When I have leisure time, I hang out on YouTube, webinars, and virtual libraries. Online class is gradually changing my learning habits and behavior, enriching skills and knowledge. Now, I get solutions to problems searching virtual sources that help to build my new habit through online class practices...

Based on interview finding with master level students we came to the issues of quantitative survey and designed structural questionnaires. From this interview, we derived the issues of the survey to students and came to the conclusion that faculty surveys are essential to understand the perceptions, nature of cooperation and support, and technologically friendliness to judge and enhance the effectiveness of online classes.

Based on the literature search as well as a preliminary interview, three specific factors i.e. teacherspecific, student-specific, and infrastructure specific actors surrounded by the environment are responsible for learning effectiveness of online mode of instruction during a pandemic. 


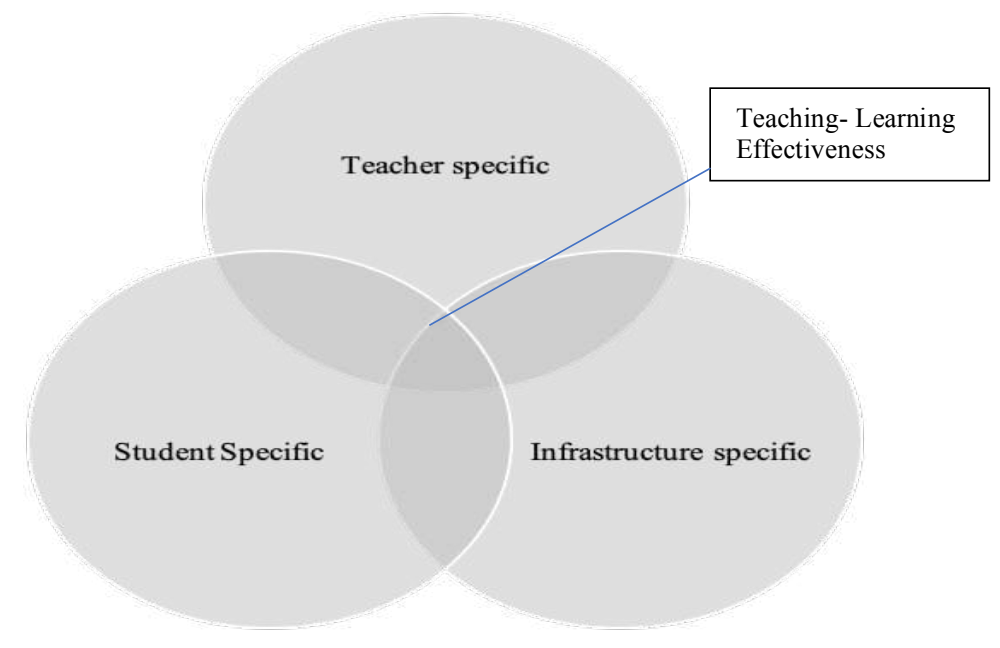

Figure 1. Issues specifying online learning effectiveness during pandemic

\section{Stage Two: Structural Survey and Analysis}

Based on the first stage interview with representative students, a survey was conducted with the students undertaking online classes during the pandemic period of COVID-19. Altogether 158 students of undergraduate (Bachelor), and graduate (Master) levels of diversified programs participated in the survey that fulfills the cross-sectional features within a timeframe of a pandemic. The survey period was 20 days only from April 20 to May 10, 2020. Table 1 provides a profile of the details of respondents participating in the survey.

Table 1. Demographic profile of respondents

\begin{tabular}{|c|c|c|c|c|}
\hline & Demographic category & $\begin{array}{c}\text { Undergraduate } \\
\text { level }\end{array}$ & $\begin{array}{c}\text { Graduation } \\
\text { level }\end{array}$ & Total $(\%)$ \\
\hline \multirow{3}{*}{ Gender } & Male & 45 & 35 & 50.63 \\
\hline & Female & 44 & 37 & 49.37 \\
\hline & Total Number & 89 & 69 & 100 \\
\hline \multirow{5}{*}{$\begin{array}{c}\text { Employment } \\
\text { situation }\end{array}$} & Full-Time Government & 0 & 6 & 3.79 \\
\hline & Full Time Private & 0 & 27 & 17.09 \\
\hline & Part-Time employed & 6 & 3 & 5.69 \\
\hline & Unemployed & 83 & 36 & 75.31 \\
\hline & Total & 89 & 69 & 100 \\
\hline \multirow{5}{*}{$\begin{array}{c}\text { Living } \\
\text { arrangement } \\
\text { during } \\
\text { COVID-19 }\end{array}$} & Living alone & 2 & 4 & 3.79 \\
\hline & Living with roommate & 0 & 3 & 1.89 \\
\hline & Living with parents & 54 & 27 & 51.27 \\
\hline & Living with spouse & 33 & 38 & 44.94 \\
\hline & Total & 89 & 69 & 100 \\
\hline
\end{tabular}




\section{Unmarried}

Marital status

Married with no child

Married with children

Total
89

0

0

89
55

6

8

69
91.14

3.79

5.06

100

Maximum students belong to the undergraduate level followed by the graduate level. The majority of students were unmarried, unemployed, and living with parents.

Table 2. COVID-19 pandemic effects to respondents

\begin{tabular}{clccc}
\hline & Academic level & $\begin{array}{c}\text { Bachelor } \\
\text { level }\end{array}$ & Master level & Total \\
\hline \multirow{4}{*}{ Level of } & Completely unaffected & 18 & 9 & 17.09 \\
COVID-19 & Somewhat unaffected & 3 & 0 & 1.90 \\
effects & Neutral & 20 & 16 & 22.78 \\
& Somewhat affected & 28 & 31 & 37.34 \\
& Affected & 12 & 12 & 15.19 \\
& Badly affected & 8 & 1 & 5.70 \\
\hline
\end{tabular}

Table 2 shows that the majority of students were suffering in any form. Though, very few reported they were badly affected by the pandemic, more than 50 percent of respondents reported affected at a low to moderate degree. Depending upon the level, graduation level students were affected comparatively higher in percentage terms (about 50 percent). Generally, the prolong of lockdown and social distancing in academic institutes determine the level of effect of COVID-19, and the survey was done within the two months of the pandemic.

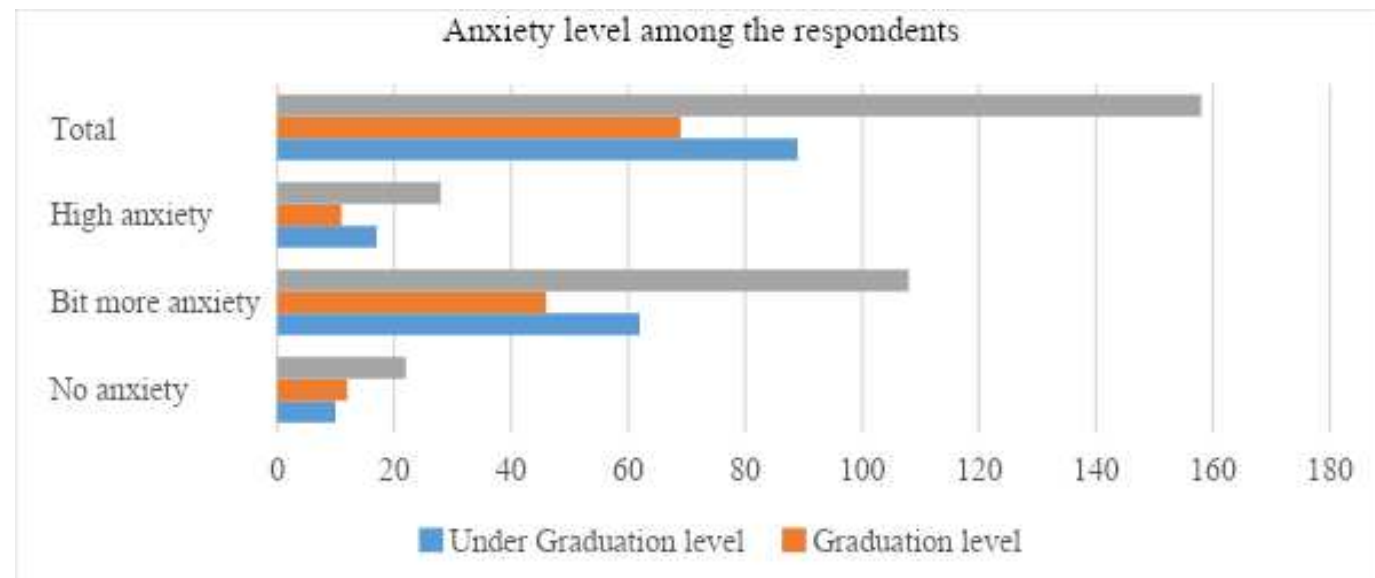

Figure 2. Anxiety level caused by COVID-19 pandemic 
The majority of the students (86.6 percent) reported that they experienced anxiety at different levels. 36.7 percent experienced very little anxiety followed by 42.4 percent experienced a bit more anxiety and 7 percent reported high anxiety. In comparison, students studying graduation (Master) level experienced more anxiety. This could be because of greater responsibility for their financial arrangement or because of thinking obstruction of completing their formal academic degree to have a start-up of their formal career.

Table 3.Quality of internet connectivity

\begin{tabular}{llcccc}
\hline & & Good & Fair & Poor & Total \\
\hline Current dwelling place & Kathmandu & 46 & 27 & 11 & 84 \\
during COVID-19 & Out of Kathmandu & 28 & 28 & 18 & 74 \\
\hline Total & & 74 & 55 & 29 & 158 \\
\hline
\end{tabular}

The survey revealed that the internet connectivity out of Kathmandu is comparatively poorer than in Kathmandu as expected. 54.76 percent of students based on Kathmandu reported that the internet is good followed by 32.10 percent fair and only 13.10 percent poor. However, students out of Kathmandu reported that only 37.84 percent reported their internet is good followed by 37.84 percent fair and 24.32 percent poor. This indicates that the online learning out of Kathmandu could be less effective in comparison to Kathmandu because of poor internet facility.

At all levels, the majority of the students believe that they get an opportunity for higher-level understanding and advanced learning. This response urges to uplift the infrastructure facilities so that alternative modes of education can be launched to those who need additional support and/or cannot attain their classes regularly. About 68 percent of students believe that they get the opportunity of advancing their education through online compared to 16.45 percent of respondents having a perception of lower opportunity. 
Table 4. Anxiety caused by COVID-19 versus willingness to learn

\begin{tabular}{|c|c|c|c|c|c|c|}
\hline & & & \multicolumn{4}{|c|}{ COVID-19 caused anxiety level } \\
\hline & & & $\begin{array}{c}\text { No } \\
\text { anxiety }\end{array}$ & $\begin{array}{c}\text { Little } \\
\text { anxiety }\end{array}$ & $\begin{array}{c}\text { High } \\
\text { anxiety }\end{array}$ & Total \\
\hline \multirow{18}{*}{$\begin{array}{l}\text { Willingness to } \\
\text { learn }\end{array}$} & \multirow[b]{2}{*}{ Lower than usual } & Count & 6 & 38 & 9 & 53 \\
\hline & & $\begin{array}{l}\text { Expected } \\
\text { Count }\end{array}$ & 7.4 & 36.2 & 9.4 & 53 \\
\hline & \multirow[b]{2}{*}{ About the same } & Count & 5 & 23 & 2 & 30 \\
\hline & & $\begin{array}{l}\text { Expected } \\
\text { Count }\end{array}$ & 4.2 & 20.5 & 5.3 & 30 \\
\hline & \multirow[b]{2}{*}{ Higher than usual } & Count & 11 & 47 & 17 & 75 \\
\hline & & $\begin{array}{l}\text { Expected } \\
\text { Count }\end{array}$ & 10.4 & 51.3 & 13.3 & 75 \\
\hline & \multirow[b]{2}{*}{ Total } & Count & 22 & 108 & 28 & 158 \\
\hline & & $\begin{array}{l}\text { Expected } \\
\text { Count }\end{array}$ & 22 & 108 & 28 & 158 \\
\hline & & & \multicolumn{4}{|c|}{ Quality of internet connectivity } \\
\hline & & & Good & Fair & Poor & Total \\
\hline & \multirow[b]{2}{*}{ Lower than usual } & Count & 26 & 19 & 8 & 53 \\
\hline & & $\begin{array}{l}\text { Expected } \\
\text { Count }\end{array}$ & 24.8 & 18.4 & 9.7 & 53 \\
\hline & \multirow[b]{2}{*}{ About the same } & Count & 16 & 9 & 5 & 30 \\
\hline & & $\begin{array}{l}\text { Expected } \\
\text { Count }\end{array}$ & 14.1 & 10.4 & 5.5 & 30 \\
\hline & \multirow[b]{2}{*}{ Higher than usual } & Count & 32 & 27 & 16 & 75 \\
\hline & & $\begin{array}{l}\text { Expected } \\
\text { Count }\end{array}$ & 35.1 & 26.1 & 13.8 & 75 \\
\hline & \multirow[b]{2}{*}{ Total } & Count & 74 & 55 & 29 & 158 \\
\hline & & $\begin{array}{l}\text { Expected } \\
\text { Count }\end{array}$ & 74 & 55 & 29 & 158 \\
\hline
\end{tabular}

Table 4 reveals that there is no clear distinction in lower willingness to learn and anxiety. The percentage of students having a low willingness to learn with higher anxiety and the percentage of students reporting low willingness to learn within the lower anxiety have no distinctive distribution. But, students who reported a higher willingness to learn have very little or no anxiety. Based on the observation, we can presume anxiety level differs in the level of willingness to learn. To make a concrete understanding of this result, we did Chi-square test and Cramer's V value.

Table 5 provides the distribution of responses on willingness to learn across the different levels of quality of internet connectivity. From this information, an initial guess can be made as good connectivity of the internet helps to increase the willingness to learn.

Table 5. Chi-Square Tests to examine the association between anxiety and willingness to learn

Asymptotic Significance (2-

Value df sided)




\begin{tabular}{|c|c|c|c|}
\hline Pearson Chi-Square & $4.315 \mathrm{a}$ & 4 & 0.365 \\
\hline Likelihood Ratio & 4.889 & 4 & 0.299 \\
\hline $\mathrm{N}$ of Valid Cases & 158 & & \\
\hline Cramer's V & 0.117 & & 0.365 \\
\hline \multicolumn{4}{|c|}{$\begin{array}{l}\text { a } 1 \text { cells }(11.1 \%) \text { have expected count less than } 5 \text {. The minimum expected count is } \\
4.18 \text {. }\end{array}$} \\
\hline \multicolumn{4}{|c|}{ Chi-Square Tests to examine the association between anxiety and willingness to learn } \\
\hline & Value & df & $\begin{array}{l}\text { Asymptotic Significance (2- } \\
\text { sided) }\end{array}$ \\
\hline Pearson Chi-Square & $1.567 \mathrm{a}$ & 4 & 0.815 \\
\hline Likelihood Ratio & 1.576 & 4 & 0.813 \\
\hline $\mathrm{N}$ of Valid Cases & 158 & & \\
\hline Cramer's V & 0.07 & & 0.815 \\
\hline
\end{tabular}

a 0 cells $(0.0 \%)$ have expected count less than 5 . The minimum expected count is 5.51 .

There is no association between the level of willingness to learn and the level of anxiety $\left(\chi^{2}=\right.$ 4.315, $\mathrm{df}=4$, sig. 0.365 , Cramer's $\mathrm{V}=0.117$ ). This helps to conclude that the anxiety caused by pandemic may not cause for lowering the effectiveness of online instruction in teaching-learning as the learning willingness in students is not affected by anxiety. As with anxiety, there was a primary concern of stakeholders regarding the internet excess and its quality in willingness to learn and the effectiveness of the online instruction.

Likewise, it assured that there is no association between internet quality and the learning willingness $\left(\chi^{2}=1.567\right.$, df $=4$, sig. 0.815, Cramer's $\left.\mathrm{V}=0.070\right)$. These descriptions lead the discourse towards the effectiveness of mode of education as the academic level or quality of internet connectivity does not influence their willingness to learn even in the pandemic situation. For further inquiry, the effectiveness of online learning experience during the pandemic based on an academic level as well as internet quality was examined as suggested by students in the interview.

Table 6. Online class effectiveness

\begin{tabular}{|c|c|c|c|c|c|c|}
\hline & & Online class exp & ce comp & to face-to-f & class & \\
\hline \multirow{7}{*}{$\begin{array}{l}\text { Academic } \\
\text { Program }\end{array}$} & & & $\begin{array}{l}\text { Much } \\
\text { worse }\end{array}$ & $\begin{array}{l}\text { About the } \\
\text { same }\end{array}$ & Much better & Total \\
\hline & \multirow{2}{*}{$\begin{array}{l}\text { Under } \\
\text { graduation }\end{array}$} & Count & 40 & 23 & 26 & 89 \\
\hline & & Expected Count & 38.9 & 20.3 & 29.9 & 89 \\
\hline & \multirow{2}{*}{ Graduation } & Count & 29 & 13 & 27 & 69 \\
\hline & & Expected Count & 30.1 & 15.7 & 23.1 & 69 \\
\hline & \multirow{2}{*}{ Total } & Count & 69 & 36 & 53 & 158 \\
\hline & & Expected Count & 69 & 36 & 53 & 158 \\
\hline & & \multicolumn{5}{|c|}{$\begin{array}{l}\text { Quality of internet connectivity and effectiveness of online mode of } \\
\text { education }\end{array}$} \\
\hline & & & $\begin{array}{l}\text { Much } \\
\text { worse }\end{array}$ & $\begin{array}{l}\text { About the } \\
\text { same }\end{array}$ & Much better & Total \\
\hline
\end{tabular}




\begin{tabular}{lclcccc} 
& \multirow{2}{*}{ Good } & Count & 23 & 25 & 26 & 74 \\
& & Expected Count & 32.3 & 16.9 & 24.8 & 74 \\
\cline { 2 - 6 } Quality of & \multirow{2}{*}{\begin{tabular}{l}
\multirow{2}{*}{ Fair } \\
connernet
\end{tabular}} & Count & 28 & 7 & 20 & 55 \\
\cline { 2 - 6 } & & Expected Count & 24 & 12.5 & 18.4 & 55 \\
\cline { 2 - 6 } & \multirow{2}{*}{ Poor } & Count & 18 & 4 & 7 & 29 \\
& & Expected Count & 12.7 & 6.6 & 9.7 & 29 \\
\cline { 2 - 6 } & \multirow{2}{*}{ Total } & Count & 69 & 36 & 53 & 158 \\
& & Expected Count & 69 & 36 & 53 & 158 \\
\hline
\end{tabular}

Based on the description in table 6 , it can be argued that graduate-level students feel comparatively more effective online class experiences than undergraduate level students. Likewise, students with poor internet reported much worse effectiveness of online classes. For confirmation of the postulates, the Chi-square test was estimated as follows.

Table 7. Chi-Square test of academic level to the effectiveness of online classes

\begin{tabular}{|c|c|c|c|}
\hline & Value & $\mathrm{df}$ & $\begin{array}{c}\text { Asymptotic Significance (2- } \\
\text { sided) }\end{array}$ \\
\hline Pearson Chi-Square & $2.051 \mathrm{a}$ & 2 & 0.359 \\
\hline Likelihood Ratio & 2.056 & 2 & 0.358 \\
\hline Cramer's V & 0.114 & & 0.339 \\
\hline $\mathrm{N}$ of Valid Cases & 158 & & \\
\hline \multicolumn{4}{|c|}{ a 0 cells $(0.0 \%)$ have expected count less than 5 . The minimum expected count is 15.72 . } \\
\hline \multicolumn{4}{|c|}{ Test of quality of internet connectivity to the effectiveness of online mode of education } \\
\hline & Value & $\mathrm{df}$ & $\begin{array}{l}\text { Asymptotic Significance (2- } \\
\text { sided) }\end{array}$ \\
\hline Pearson Chi-Square & $13.944 \mathrm{a}$ & 4 & 0.004 \\
\hline Likelihood Ratio & 14.157 & 4 & 0.004 \\
\hline Cramer's V & 0.312 & & 0.004 \\
\hline $\mathrm{N}$ of Valid Cases & 158 & & \\
\hline
\end{tabular}

Chi-square estimation makes support of the findings that there is no difference between the level of education in a feeling of effectiveness of the online classes $\left(\chi^{2}=2.051, \mathrm{df}=2\right.$, sig. $=0.359$, Cramer's V $=0.114)$. This result reveals that there is no association between the effectiveness of the online mode of education and the academic level of students.

Chi-square test provides sufficient evidence that the sample represents the population. This also reveals that there is an association between the qualities of internet connectivity and the effectiveness of the online mode of education during COVID-19. This result supports the major 
concern of the students participating in interview discussion regarding probable effectiveness of online classes during COVID-19 especially to the students of on-class mode.

In support of the agendas raised through the interview, few open-ended questionnaires were included in the survey arguing that the open-ended questions provide the opportunities for expressing each respondent's feelings without limitations of researchers. Regarding the question of what do you realize the online mode of instruction in comparison to on-class mode, the majority of the respondents reported that it could be the best action to link students, teachers, and the institutions during such an uncertain pandemic like COVID-19. One of the graduate-level students holding a job, has stated as:

“...Online medium instruction is more flexible in terms of time, traveling cost, and place for attending classes especially for working students..."

Majority of the students $(61 \%)$ reported that the online mode of instruction is free from hectic schedule becomes more effective as it is flexible in terms of time, availability of teaching materials, place and sitting arrangement. Many students (45\%) highlighted the benefit of online classes during a pandemic and felt good sources for managing anxieties as these classes make them engaged in taking classes, preparing assignments, and searching additional materials. The majority of the students $(52 \%)$ stated that they have enhanced their exposure to world-class changes in education mode. Nearly $34 \%$ percent of students reported that they get opportunities to have oneon-one interaction with teachers as they feel uncomfortable asking or sharing their problems in regular class settings. Students also added the benefits of online mode of instruction for adding presentations, videos, and audios which generally are not widely practices in on-class teaching in Nepali Universities.

Besides the advantages of online mode of instruction, respondents were asked to report their experience of feeling uncomfortable with online classes. They reported that they feel difficulties to deal with numerical computations (75\%). The majority of the students $(79 \%)$ complained that their classes remain ineffective with poor internet connectivity. As many parts of Nepal have no or low internet connectivity, many students may lack laptops or mobile phones to take online classes effectively. One of the graduate-level student expressed as:

.... “...effectiveness of online classes depends upon the technology friendliness of both students as well as faculties. Many faculties have to be trained to enhance presentation skills, video-sharing, and motivating students for active participation in obtaining, sharing, and presentation in class. Assignment in many subjects is not properly evaluated...."

This could be the most important insight for developing the effectiveness of online classes. Nearly 35 percent of students also reported that they lose their attention from their classes because of 
setups at home. At the same time, 60 percent of students reported that they face problems of asking questions because of the faculties' one-way presentation. Similarly, one student pursuing MBA degree has missed on-class classes because:

“...I miss those presentations \& case studies presented in front of the classes \& discussions with the joint effort of teacher \& student. .... class environment provides more opportunity for learning things, management, and people from friends and other people..... Not only the classroom environment; but the social setting also helps to learn to future managers...."

Regarding suggestions to improve the effectiveness of online classes, almost all students suggested to University authorities and even to the government to ensure low-cost high-intensity internet facility. They suggested the authority to train teaching faculties for using online applications and also to the students. Each faculty as well as students expect to get university id (university email id) of official online education portals and applications. Students also have suggestions for faculties as:

“...teachers need to encourage students for involvement in-class discussion, need to explore new ideas to make numerical based classes more effective, providing students with assignment along with the examples to solve them. In case of theorybased class, ask students to make a presentation on a specific topic and allow him/her to present in online classes, and feedback to their assignment..."

\section{Stage Three: Findings from Faculty Interview}

For online teaching experiences, a semi-structured interview with 14 faculties representing different programs and levels of students was conducted. Among them majority faculties (71.43\%) had prior experience of teaching online in different occasions. Among these Faculties, 8 of them (57.14\%) were teaching at the Master level, and rest were engaged in teaching undergraduate level programs. Regarding the nature of subjects they teach, the majority were of non-numeric courses, and remaining were teaching a mix of numeric and non-numeric nature along with one who teaches only numeric subject. A large number of faculties (42.85\%) teach both in government as well as private colleges, $28.87 \%$ teach in only government campuses and similar number teach in private colleges. Faculties were asked to have self-report about their level of familiarity with technology for online teaching, 50\% reported that they are good in handling technology while $35.71 \%$ of them reported that they are average while $14.28 \%$ reported that they are learning in handling technology for online teaching. They expressed their experience with online teaching in the following points.

Table 8. Experience expressed by faculties about online teaching during COVID-19 pandemic 
- Integration of technology in the teaching-learning process.

- Record of teaching contents and class for future use and revision

- Save time, cost and flexibility

- No class noise and wide geographical area coverage

- Easy to assign task to students and collection of their assignment

- Easy access to national and international resource person for guest classes

Faculties especially based on the on-class mode of teaching enjoy online classes because of the opportunity of being connected with technology for teaching, collecting teaching materials, sharing such materials to students, and connecting with international resource persons. Such opportunities expand the horizon of their knowledge and enhance the opportunity of personal and professional growth. More importantly, they believe that the online mode of teaching becomes a strong tool to connect geographically diverse students in the virtual classroom. They do believe that online teaching helps to manage personal-professional time. However, some technologyrelated problems they outlined during their teaching during the COVID-19 pandemic.

Table 9. Technology-related problems

- Unstable internet and power supply

- Depend on time-limited version of online teaching application (no University/ college online platform)

- Writing problem/Issue of whiteboard

- Unavailability of devices/equipment and knowledge of use with all students

- Difficult to demonstration of steps as in on-class mode

- Costly internet

The next question was about what technology-related factors are hindering to the faculties to make their online class effective. Many of the faculties reported the same factors as poor internet connectivity and unstable power supply. These are the common problems in Nepal. Internet is expensive, limited geographical coverage, and unstable if there is connectivity. According to respondents, internet package in Nepal is comparatively expensive which discourages students to search reading materials through the internet. Power supply, though it is more stable in these days, also stresses to students as well as instructors. Many of the students join their classes through their mobile phones which may not fulfill all the teaching objectives like presentations. Some faculties also identified that the students should have basic knowledge of technology, not limited to only operate the application but to perform their tasks in it. As many students submit their assignments in scanned copy after writing their tasks in a copy. Along with the technology-related factors, 
faculties reported that students are not ready to take online classes because of many factors. To identify these many factors related to students, faculties were asked what students related problems do you realize in online classes responsible to make the classes less effective. Following major responses were reported by them:

Table 10. Students related problems

- Internet network interruption

- Late joining and early leaving

- Less interest in face to face interaction and discussion

- Reading stress of student and unable to pay attention

- Problems of devices/ equipment and their knowledge for online class

- Poor personal commitment

- Difficulties for assignment, evaluation (grading) and control

- Problems of reading students psychology, attitude, behavior and expectations

Table 10 summarizes the faculties discomfort in teaching online because of students in which almost all the respondents commented that the students join the class late, disconnect and reconnect the classes frequently. This could be because of the poor strength of the internet. They also reported that most of the students seem to have low commitment. Few students try to cheat as they connect the class and maybe engaged in household tasks or try to remain isolated. Many of the respondents feel that class is less effective because of the lack of face-to-face interaction with students. Students even deny submitting the assignments. More generous comments 'mental stress of students especially those who are in the 'red' area of pandemic. Faculties also commented that many students even express their higher expectations from their instructors in terms of materials as well as sympathy for attendance.

Adding the seriousness of students on learning, faculties reported that the majority of the students are serious more than average on their study. Especially, the faculties who were engaged in teaching the Master level have noticed that the majority of their students regularly submit their assignments. This could be because of their familiarity with technology and/or job holder students who want to utilize their leisure time. 
Despite such several technology-related hurdles, faculties judge the effectiveness of their teaching online. They were asked to judge the effectiveness of their online classes during the pandemic. The majority (79\%)of them reported that the online teaching model is effective followed by $14 \%$ most effective and $7 \%$ satisfactory. Comparing to students' response this finding seems a little bit contradictory as $35.54 \%$ reported most

- Satisfactory - Effective - Most effective

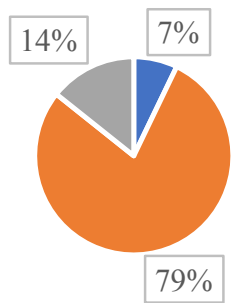

Figure 3: Effectiveness of Online class (Instructor's self judgement) effective, $22.78 \%$ about the same and rest of other i.e. $43.67 \%$ reported less effective than on-class class. This led us to conclude that teaching faculties and the students' perceptions are not much different but aligning the same.

Table 11. Faculties' expectation from Campus/College/University to make online class effective

- Technologically designed and updated faculties with broadband internet

- Revision of curriculum based on online mode of teaching

- Investment on infrastructure to match online program

- Designing University online teaching platform and university id for all

- Development of alternative mode of learning

- Strengthen administration for online management

- Regular orientation to all- faculties, administration and students

Regarding what the Faculties expect from their campus/college/university to make the online classes more effective, all of them expect in short term to get a permanent ID of virtual class like Microsoft Team and Zoom so that there will be no hurdle of untimely disconnection and material management and for long-term start to design university's own online platform. They also suggest to orient faculties, administrative personnel as well as students. At the same time, they express their suggestions to their university authority to update the syllabus for the integration of courses with technology, and universities need to provide alternative modes of education to the full time working students. Regarding the changing behavior of students, faculties feel that they are more positive. Faculties observed that majority of the students who participate in online classes show positive changes in their behavior. Describing the probable reason for the change in behavior, the majority of the faculties argue that during the pandemic period, the study helps them to be engaged so that they can relief from stress. 
Thinking positively, Faculties express that students are having positive and supportive in online learning because of the new mode of discussion, presentation, searching for academic resources. This is because of their seriousness on the timely completion of their course semester as their university announced the continuation of their course. Many of the students are future managers who think the pandemic provided a better opportunity of being technology-friendly. Some of them said that students are paying more positive having seriousness as they think their institution paid the concern to handle complexities on time. Faculties reported that the majority of students are positive towards online teaching but they also reported that students have worries regarding their study. Answering the question of whether you suggest continuing online mode of teaching as an alternative mode, the majority of faculties agreed. They suggest authority to invest in infrastructure and maintain permanent IT department, revisit courses, and organize orientation to faculties, administrative staff, and student. Faculties are interested to arrange online classes during on-class time schedule to make feeling of continue of class like before pandemic to both students and faculties. They suggest to the students to be more focused and managed study time and environment. Likewise, they suggest to their fellow faculties to be more prepared, positive, updated, and proactive to make such classes more effective.

\section{Conclusion}

In this study, we come to the understanding that the COVID-19 outbreak has been a game-changer in the way teaching happening around the globe. Nepal is no exception from this reality as Bolery and Lord (2020) mentioned the COVID-19 creates the right time for institutional transformation. It creates opportunities to explore new technologies for the education sector realizing the significance of the use of technology in the teaching-learning process suggested by Fang and his colleagues (Fang et al., 2019). The technology of education is not only focused on the use of technology devices but also deals with the systematic application of resources scientifically incorporating the right pedagogy to transform knowledge and skills effectively.For the online teaching-learning process, each university needs to develop an online mode of education as an alternative mode with developing an education-friendly curriculum, updated technology, designated faculty, and proactive administration.

Effectiveness of online classes especially in pandemics depends upon triad factors relationship as infrastructure specific, students specific, and teacher specific. Teaching is perceived as good when clear goals are formulated, course become interesting and relevant, teaching constructively aligned for interaction and support. Hailikari and Parpala (2014) rightly mentioned that a good relationship with teachers and students for constructive feedback is required for effective teaching-learning activities. Individual behavior, environmental factors, and personal factors constantly influence and determine one another bi-directionally (Bandura, 1986). Nepalese faculty and students have a positive attitude and behavior to prepare regular learning, consultation, active participation, 
genuine commitment, dedication, and listening during the COVID-19 pandemic which can be changed over the period as suggested by Newport (2005). However, they are surrounded by technical nonacademic problems like dedicated internet, cost of internet, regular power supply, online devices, etc. Similar to the findings of Collis (1995), faculty characteristics are a strong foundation for the effectiveness of online teaching-learning. The designated faculty is required for coordination and development of online courses though Nepalese faculties are proactive in doing individual efforts rather than institutional efforts (Author, 2012). For developing online classes as alternative teaching-learning activities especially in such pandemic or other critical situations, universities need to develop techno-friendly curriculum, trained and designed faculty, proactive management, assurance of IT infrastructure, and supportive students. Online classes during such pandemic can be useful techniques to control the anxiety of students and teachers so that students and teachers can be free from probable psychological disorders. Management of the transition period is difficult but shows the leadership capabilities and recognized as a catalyst for change. There are a lot of examples of successful leaders during the COVID-19 pandemic who manage the transitions of their universities. For example, Zhejiang University managed 500 courses online just two weeks during the COVID-19 pandemic (World Economic Forum, 2020). Therefore, it is an expectation of all stakeholders of Tribhuvan University that senior leaders taking confidence with the middle level will craft the direction and strategies to cope with the current critical situation of pandemic and become an academic leader in the south Asian region.

\section{Way forward}

The effects of a COVID-19 pandemic are still early to estimate throughout the world. Its effects are witnessing vulnerablein some sectors like aviation, hotel, and tourism. Though it becomes madness to compare with life, the education industry is one of the most important sector which is connected with startup, growth, and prosperity of hundreds of thousand children and youth. The COVID-19 pandemic has been creating sever pain to almost all areas of human life and economic activities. Realizing these facts, plenty of research rooms are open to examining its impacts, opportunities, and threats during pandemic period integrating multiple disciplines like peer support (McBeath et al., 2017), personal characteristics of students (Prevatt et al., 2011), self-control and time management (Kim \& Seo, 2015; Mbuva, 2011), willingness to study (Leonard \& Insch, 2005), student attention (Cao et al., 2020), acceptance of responsibility (Robinson, 1993), ability to concentrate (van den Bogaard, 2012), ability to react to change and mistake (Nonis et al., 2005), faculty attitudes (Yao et al., 2020), teaching strategies (Hattie, 2015) and many others . Similar

study can be conducted longitudinally to judge further effectiveness and chaos regarding online mode during the pandemic period in developing countries. 


\section{References}

Abdulamir, A. S. \& Hafidh, R. R. (2020). The possible immunological pathways for the variable immunopathogenesis of COVID-19 inflections among healthy adults, elderly and children. Electronic Journal of General Medicine, 17(4).https://doi.org/10.29333/ejgm/7850

Bamberger P. A. (2018). Amd-clarifying what we are about and where we are going. Academy of Management Discoveries 4(1): 1-10. https://doi.org/10.5465/amd.2018.0003

Bandura, A. (1986). Social foundations of thought and action: a social cognitive theory. Englewood Cliffs: Prentice-Hall.

Barr, B. \& Miller, S. (2013). Higher Education: The online teaching and learning experience. Retrieved from https://www.google.com/url?sa=t\&source=web\&rct=j\&url=https://files.eric.ed.gov/fulltext/ ED543912.pdf\&ved=2ahUKEwiS3tKI2N3oAhUm2EKHfNoCR8QFjABegQIAxAB\&usg= AOvVaw10Sal8UOXPU8DFS3h782jT

Basilaia, G. \& Kvavadze, D. (2020). Transition to online education in schools during a SARSCoV-2 Coronavirus (COVID-19) pandemic in Georgia. Pedagogical Research, 5(4), 1-9. https://doi.org/10.29333/pr/7937

Blewett, A. E. (2000). Help cards for patients. Psychiatric Bulletin, 24, 276.

Brahmbhatt, M.\& Dutta, A. (2008). On SARS type economic effects during infectious disease outbreaks. The World Bani: Washington, DC, USA.

Candy, P. C.; Crebert, G. \& O’Leary, J. (1994). Developing lifelong learners through undergraduate education, national board of employment, education and training. Australian Government Publishing Service, Canberra.

Cao, W.; Fang, Z.; Hou, G.; Han, M.; Xu, X.; Dong, J. \& Zheng, J. (2020). The psychological impact of the COVID-19 epidemic on college students in China. Psychiatry Research, 287. Retrieved from: https://doi.org/10.1016/j.psychres.2020.112934

Collis, B. (1995). Anticipating the impact of multimedia in education: Lessons from the literature. Computer in Adult Education and Training, 2, 2, 136-49.

Crawford, J.; Butler-Henderson, k.; Rudolph, J.; Malkawi, B.; Glowatz, M.; Burton, R.; Magni, P. A. \& Lam, S. (2020). COVID-19: 20 countries' higher education intra-period digital pedagogy response. Journal of Applied Learning and Teaching, 3, 1, 1-20. https://doi.org/10.37074/jalt.2020.3.1.7 
Daft, R. L. \& Lengel, R. H. (1986). A proposed integration among organizational information requirements, media richness, and structural design. Management Science, 32, 554-71.

Dillon, C. L. \& Gunawardena, C. N. (1995). A framework for the evaluation of telecommunications-based distance education. In Steward, D. (Ed.), Selected Papers from the $17^{\text {th }}$ Congress of the International Council for Distance education, Vol. 2, Open University, Milton Keynes, 348-51.

Fang, C.; Wang, G. \& Huang, B. (2019). Can information technology promote the development of students' cognitive abilities? An estimate based on the net effect of educational value added instruments. Open Edu Res, 25, 4, 100-110.

Gondauri, D.; Mikautadze, E. \& Batiashvili, M. (2020). Researh on COVID-19 virus spreading statistics based on the examples of the cases from different countries. Electronic Journal of General Medicine, 17, 4, em209. https://doi.org/10.29333/ejgm/7869

Hailikari, T., \& A. Parpala. 2014. What impedes or enhances my studying? the interrelation between approaches to learning, factors influencing study progress and earned credits." Teaching in Higher Education, 19, 7: 812-824. doi:10.1080/13562517.2014.934348.

Hattie, J. (2015). Visible learning: A synthesis of over 800 meta analysis relating to achievement. Beijing, Educational Science Publishing House.

Haynes, R. M.; Pouraghabagher, R. \& Seu, A. (1997). Interactive distance education alliance (IDEA): collaborative model delivers on demand. The Journal: Technological Horizons in Education, 24, 8, 60-63.

Karen, J. B. T. \& Cathy, M. D. T. (2020). Philippine teachers' practices to deal with anxiety amid COVID-19. Journal of Loss and Trauma,https://doi.org/10.1080/15325024.2020.1759225

Kim, K. R. \& Seo,E. H. 2015. The relationship between procrastination and academic performance: A meta-analysis." Personality and Individual Differences, 82: 26-33. doi:10.1016/j.paid.2015.02.038

Lee, M. \& You, M. (2020). Psychological and behavioral responses in South Korea during the early stage of Coronavirus disease 2019 (COVID-19). International Journal of Environmental Research and Public Health, 17, 2977, 1-14.

Leidner, D. E. \& Jarvenpaa, S. 1. (1993). The information age confronts education: case studies on electronic classroom. Information System Research, 4, 24-54.

Leite, H.; Hodgkinson, I. R. \& Gruber, T. (2020). New development: Healing at a distancetelemedicine and COVID-19. Public Money and Management. https://doi.org/10. 1080/09540962.2020.1748855. 
Leonard, N.\& Insch,G. S. (2005). Tacit knowledge in academia: A proposed model and measurement scale.The Journal of Psychology, 139, 6: 495-512

Lerner, R. M.; Fisher, C. B. \& Weinberg, R. A. (2000). Toward a science for and of the people: promoting civil society through the application of developmental science.Child Development, 71, 11-20.

Ling, G. H. T.; \& Ho, T. (2020). Effect of coronavirus (COVID-19) pandemic on social behavior: From a social dilemma perspectives. Technium Social Science Journal, 7,1, 312-320. Retrieved from https://techniumscience.com/index.php/socialsciences/article/view/423

Ludeman, R.; Osfield, K.; Hidalgo, E. I.; Oste, D.; \& Wang, H. (2009). Student affairs and service in higher education: Global foundations, Issues and Best Practices. United Nations Educational, Scientific and Cultural Organization, France. Retrieved from https://unesdoc.unesco.org/ark:/48223/pf0000183221

Marshall, J. M. (2018). Shaping the university of the future: using technology to catalyze change in university learning and teaching. Singapore: Springer.

McBeath, M., Drysdale, M. T. B. \&Bohn, N. (2017). Work-integrated learning and the importance of peer support and sense of belonging.Education + Training, 60, 1:39-53. doi:10.1108/et-05-2017-0070

Meng, L.; Hua, F. \& Bian, Z. (2000). Coronavirus disease 2019 (COVID-19): emerging and future challenges for dental and oral medicine. Journal of Dental Research,https://doi.org/10.1177/0022034520914246

Neorman, D. A. \& Spohrer, J. C. (1996). Lerner-centered education. Communications of ACM, 39, $4,15-22$.

Newport, C. (2005). How to win at college: surprising secrets for success from the country's top students. New York: Broadway Books

Nonis, S. A., Hudson,G. I.; Philhours, M. J. \&Teng, J. K. (2005). Changes in college student composition and implications for marketing education: revisiting predictors of academic success.Journal of Business Research 58, 3: 321-329. doi:10.1016/j.jbusres.2003.06.001.

Okumus, F.; van Niekern, M.; Koseoglu, M.; \&Bilgihan, A. (2018). Interdisciplinary search in tourism. Tourism Management, 69, 540-549.

Pedersen, D. B. (2015). Collaborative knowledge: The future of the academy in the knowledge base economy. In E. Westergaard \& J. S. Wiewiura (Eds.) On the facilitation of the Academy. Leiden, The Netherlands: Brill Sense. 
Poehlein, G. W. (1996). Universities and information technologies for instructional programs: issues and potential impacts. Technology Analysis \& Strategic Management, 8, 3, 273-90.

Prevatt, F.; Huijun L.; Welles, T.; Festa-Dreher, D.; Yelland, S. \& Lee, J. (2011). The academic success inventory for college students: scale development and practical implications for use with students.Journal of College Admission, 211: 26-31.

Reid, I. (1999). Towards as flexible, learner-centered environment: a draft discussion paper, mimeo. Curtin University of Technology, Perth.

Rimal, R. N.; \& Juon, H. S. (2010). Use of the risk perception attitude framework for promoting breast cancer prevention. Journal of Applied Social Psychology, 40, 287-310.

Robinson, A. (1993). What smart students know: maximum grades, optimum learning? Minimum Time. New York: Three Rivers Press

Rubin, J. T.; Amlot, R.; Page, L.;\& Wessely, S. J. B. (2009). Public perception, anxiety, and behavior changes in relation to Swine flu outbreak: Cross sectional telephone survey. BMJ, 339 , b2651.

Smyczek, S. \& Matysiewicz, J. (2013). Patient-medical unit relations in virtual environment. In Adhikari, D. R. and Gautam, D. K. (Eds.) Reshaping organizations to develop responsible global leadership, Nepalese Academy of Management.

Storck, J. \& Sproull, L. (1995). Through a glass darkly: what people learn in Videoconferences? Human Communication Research, 22, 197-219.

Taylor, S.; Zvolensky, M.; Deacon, B.; Heimberg, R.; Ledley, D. R. et al. (2007). Robust dimensions of anxiety sensitivity: development and initial validation of the anxiety sensitivity index-3 (ASI-3). Psychological Assessment, 19, 176-188.

Thamarana, S. (2016). Role of e-learning and virtual learning environment in English language learning. Research Scholar, 1 (Aug.), 1-8. https://doi.org/10.13140/RG.2.1.4665.1122.

Timmermans S, Tavory I (2012). Theory construction in qualitative research: From grounded theory to abductive analysis. Sociological Theory, 30, 3, 167-186.

UGC (2016). Education Management Information System: Report for Higher Education 2015/16. University Grants Commission (UGC), Bhaktapur, Nepal.

UNESCO (2020). Global monitoring of school closures caused by COVID-19. Retrieved from https://en.unesco.org/covid19/educationresponse.

UNESCO (2020). UNESCO Report, 'COVID-19 educational disruption and response'. Retrieved from https://en.unesco.org/covid19/educationresponse/. 
Uscher-Pines, L., et al. (2018). School practices to promote social distancing in K-12 schools: Review of influenza pandemic policies and practices. BMC Public Health, 18(1), 1-13. https://doi.org/10.1186/s12889-018-5302-3

Voery, T. (2000). Critical success factors in online education. The International Journal of Educational Management, 14, 5, 216-223.

Webster, J. \& Hackley, P. (1997). Teaching effectiveness in technology-mediated distance learning. Academy of Management Journal, 40, 6, 1282-1309.

Wetzel, C. D.; Radtke, P. H. \& Sten, H. W. (1994). Instructional Effectiveness of Video Media. Laurence Erlbaum, Hillsdale, IL.

Wheaton, M. G.; Abramowitz, J. S.; Berman, N. C.; Fabricant, L. E. \& Olatunji, B. O. (2012). Psychological predictors of anxiety in response to the H1N1n (Swine Flu) pandemic. Cogn Ther Res, 36: 210-218, https://doi.org/10.1007/s10608-011-9353-3

Wheaton, M. G.; Berman, N. C.; Franklin, J. C. \& Abramowitz, J. S. (2010). Health anxiety: latent structure and associations with anxiety-related psychological processes. Journal of PsychopaThology and Behavioral Assessment, 32, 565-574.

WHO (2020). Coronavirus disease (COVID-19) situation report. Retrieved from https://www.who.int/docs/default-source/coronaviruse/situation-reports/20200510COVID19-sitrep-111.pdf?sfvrsn=1896976f 2

World Economic Forum (2020). The COVID-19 pandemic has changed education forever. Retrieved from:https://www.weforum.org/agenda/2020/04/coronavirus-education-global-covid19online-digital-learning/

Xiang, T. T.; Yang, Y.; Li, W.; Zhang, L.; Zhang, Q.; Cheung, T. \& Ng, C. H. (2020). Timely mental health care for the 2019 novel coronavirus outbreak is urgently needed. The Lancet, Psychiatry, 7, 3, 228-229.

Yao, J.; Rao, J.; Jiang, T. \& Xiong, C. (2020). What role should teacher play in online teaching during the COVID-19 pandemic? Evidence based China. Sci Insigt Edu Front, 5, 2, 517-524. 
Figures

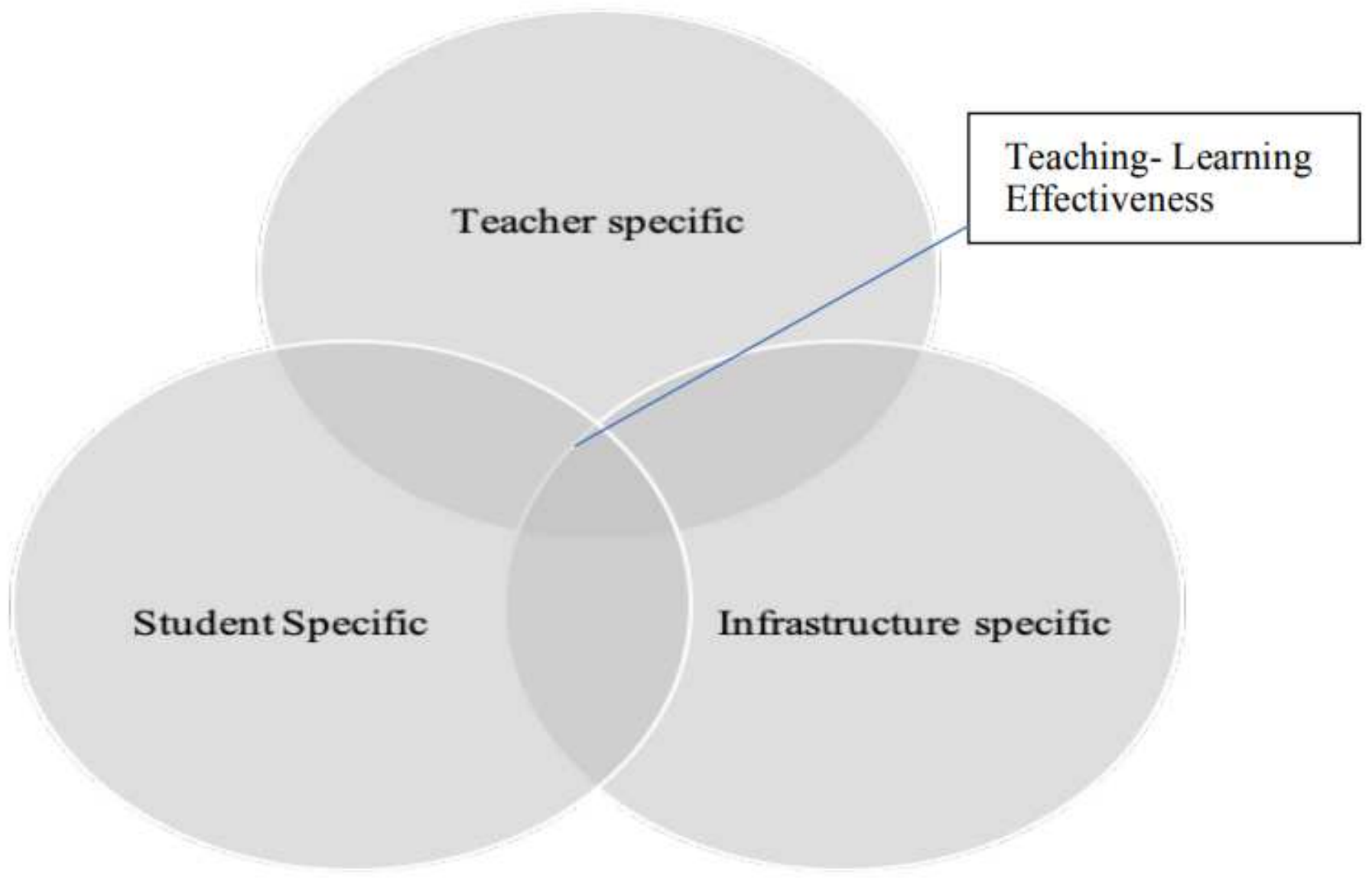

Figure 1

Issues specifying online learning effectiveness during pandemic 


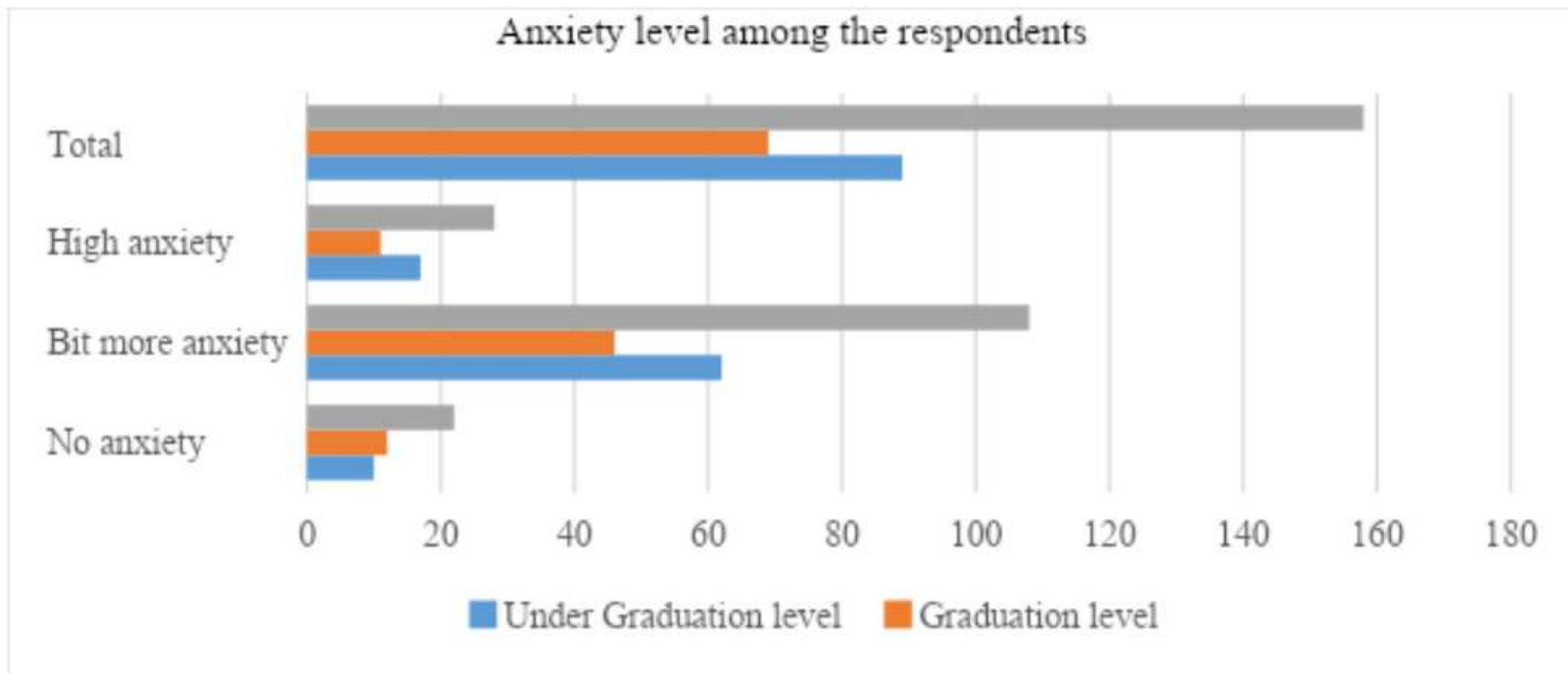

Figure 2

Anxiety level caused by COVID-19 pandemic

\section{- Satisfactory \\ - Effective \\ - Most effective}

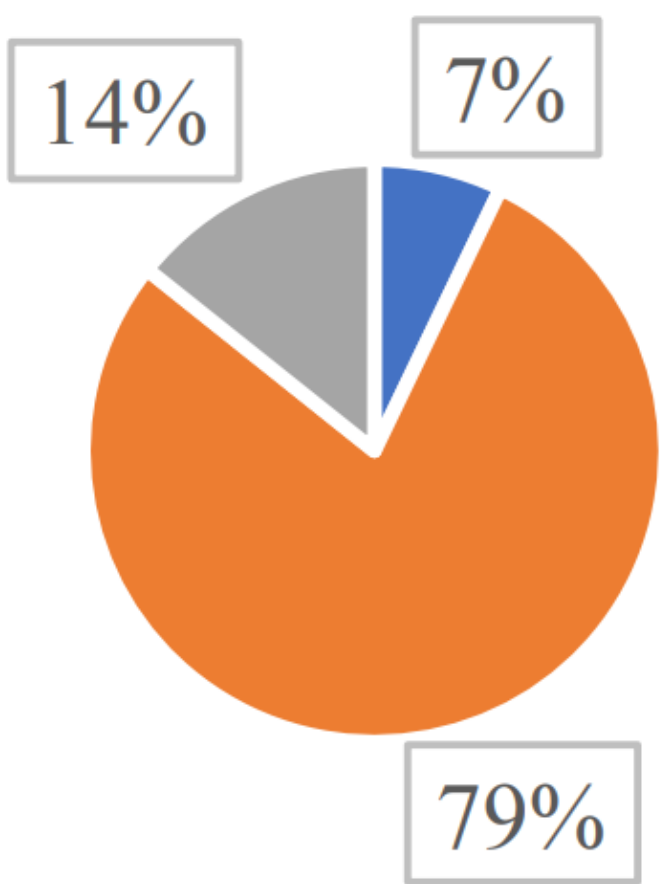

Figure 3

Effectiveness of Online class (Instructor's self judgement) 